\title{
PROPOSING A DECISION MODEL FOR PRIVATIZATION OF NEWSPRINT PAPER INDUSTRY BY APPLYING ANP
}

\author{
Majid Azizi \\ Associate professor, Faculty of Natural Resources, University of Tehran, Email: mazizi@ut.ac.ir \\ Mohammad Modarres \\ Professor, Sharif University of Technology, Email:modarres@ sharif.ir
}

\begin{abstract}
ABSTARCT
The present study aims to propose a decision model for privatization of Iran newsprint paper industry by applying ANP. Media role of newsprint paper has a very special and notable situation that must be adapted in quality and quantity with consumers` requirements. In Iran there is one newsprint paper producer that supplies 70 percent of domestic use. An appropriate privatization in newsprint paper industry will increase the rate of production and necessity of import. In this study, we use incorporation of AHP and ANP. Four possibilities of (1) Encouraging for investment (2) Reformation of rules and regulation (3) Reformation of firms ' structure and (4) Liberalization of prices, can be considered as possible solutions for expedition of privatization in newsprint paper industry. The Analytic Network Process and the Super Decision software were used to synthesize and analyze the model. In different situations, all the decisions were affected by external factors; hence, the value-weighted competency model was calculated in the first stage with the influence of external factors on the competency model. Hierarchical designs of decisions were made for each of the competencies and their subsets. Paired comparison matrices associated with the degree of importance of each of the competencies were achieved in the second stage. In the final stage, subsets of competencies' weighing values and their sub-options were identified through combination of the competencies and the best solution was obtained. Finally a sensitivity analysis of the model was also performed.
\end{abstract}

Keywords: Privatization, newsprint paper, AHP, ANP, competency 


\section{Introduction}

Newsprint paper is a main and important product in comparison with other industries, and also it has special location in press activities. Proper execution of privatization in the newsprint paper industry causes an increase in production amount. Presentation a model of decision making solution and transfer of this solution to the producers will accelerate Iran newsprint industry privatization. Successful experiences of South East Asian countries indicated that privatization of governmental firms and decrease of government role in economy cause sustainable economic growth in the country (Iran's students scientific site, 2010).

\section{Literature review}

To categorize the criteria which have been used in current research we divided them as favorable and unfavorable categories. The decision maker considers the favorable criteria as benefits and the unfavorable criteria as costs. The possible events are also divided into opportunities and risks criteria, depending whether they are considered to be positive or negative (Saaty, 2001). Alex et al (2009) announced privatization is a major tool for economic reform. Benefits of privatization in public sector which is controlled by private sector will procure maximum productivity and value via proper controlling of private sector and receiving cyclical moneys. Reviewing privatization program of Canada paper industry shows the industry has reached to a big success via converting low efficiency paper units to private sections (Mooj news agency, 2008).

\section{Hypothesis/Objectives}

The aim of this study is to present a decision model to expedite privatization of Iran newsprint paper industry. In the network merits divided into four subsections as benefits, opportunities, costs and risks. These merits are influenced by overall factors to obtain weighing values of them. This process follows the principle of analytic network process (ANP).

\section{Research Design/ Methodology}

Since BOCR are not equally important, it is necessary to prioritize them. Five possible ratings ranging from "very high" to "very low" are used. The results of the influence of the overall factors on the merits of benefits, costs, opportunities, risks, and the priority of the above mentioned merits are reported in Table1. 
Table 1: Rating of the model to obtain BOCR weighing values very high (1), high (0.51), medium $(0.252), \operatorname{low}(0.124)$, very low(0.065)

\begin{tabular}{|l|r|r|r|r|r|}
\hline & Benefits & Costs & Opportunities & Risks \\
\hline $\begin{array}{l}\text { Economic } \\
\text { (0.626) }\end{array}$ & GDP(0.5) & $\begin{array}{r}\text { Very } \\
\text { high }\end{array}$ & $\begin{array}{r}\text { Very } \\
\text { high }\end{array}$ & Very high & medium \\
& Very & medium & high & high \\
& high & & & \\
\hline Politic(0.173) & low & low & medium & medium \\
\hline Trade (0146) & $\begin{array}{r}\text { Very } \\
\text { low }\end{array}$ & high & medium & Medium \\
\hline Cultural \&social (0.055) & Medium & Medium & low & high \\
& & & & & \\
\hline Overall priorities & & 0.25 & 0.153 & 0.219 & 0.112 \\
& & & & \\
\hline
\end{tabular}

After pair wise comparisons between sub criteria for benefits, costs, opportunities and risks by ANP as well as pair wise comparisons of the criteria and choices against each other and also by following the above-mentioned merits, the results are reported. Decrease of budget deficiency and national debts(0.189), Encouragement possibility and absorption of foreign and internal investment(0.375), Limiting rules and heavy taxes(0.614)and Limiting regulative costs have the 
highest priority in terms of benefits, opportunities, costs and risks criteria, respectively. Regarding alternatives, Encouraging for investment has the highest priority with respect to benefits $(0.375)$ and opportunities $(0.385)$, costs $(0.472)$ and risks $(0.285)$.

\section{Data/ Model Analysis}

By integration of the weights of the merits of benefits, costs, opportunities and risks and the weights of choices against the above mentioned merits, the final scores are reported in Table 2. 
Table 2: Final Outcome for Priorities of the Alternatives

\begin{tabular}{|c|c|c|c|c|c|c|}
\hline $\begin{array}{l}\text { Mer. } \\
\text { Alter. }\end{array}$ & $\begin{array}{r}\text { Benefits } \\
(0.25)\end{array}$ & $\begin{array}{l}\begin{array}{l}\text { Opportu } \\
\text { nities }\end{array} \\
(0.219)\end{array}$ & $\begin{array}{c}\text { Costs } \\
\begin{array}{l}(0.15 \\
3)\end{array}\end{array}$ & $\begin{array}{c}\text { Risks } \\
\text { (0.112 } \\
\text { ) }\end{array}$ & $\begin{array}{l}\text { Final } \\
\text { Outcom } \\
\text { e } \\
\text { Additiv } \\
\text { e }\end{array}$ & $\begin{array}{l}\text { Rank } \\
\text { ing }\end{array}$ \\
\hline $\begin{array}{r}\text { Encou } \\
\text { raging } \\
\text { for } \\
\text { invest } \\
\text { ment }\end{array}$ & 0.375 & 0.385 & 0.472 & 0.285 & 0.376 & 1 \\
\hline $\begin{array}{r}\text { Liberali } \\
\text { zation } \\
\text { of } \\
\text { prices }\end{array}$ & 0.278 & 0.235 & 0.175 & 0.214 & 0.235 & 2 \\
\hline $\begin{array}{l}\text { Reformation } \\
\text { of rules and } \\
\text { regulation }\end{array}$ & 0.193 & 0.203 & 0.168 & 0.265 & 0.206 & 3 \\
\hline $\begin{array}{l}\text { Refor } \\
\text { mation } \\
\text { of } \\
\text { structu } \\
\text { re of } \\
\text { firms }\end{array}$ & 0.153 & 0.177 & $\begin{array}{l}0.18 \\
4\end{array}$ & 0.236 & 0.182 & 4 \\
\hline
\end{tabular}


As Table 2 shows encouragement for investment has the highest priority, and is the most suitable choice for privatization of newsprint paper industry in Iran. Considering the merits in decision-making, Encouraging for investment has the highest priority and the second, third and fourth are Liberalization of prices, Reformation of rules and regulation and Reformation of structure of firms, respectively.

\section{Limitations}

Limitation of the research was inconsistency ratio of the comparison matrices which have been used to obtain weighing values of the criteria. Inconsistencies exist because of the redundant information relating to the priorities in each decision matrix. If the inconsistency exceeds 0.10 , some revisions of judgments may be required. When the inconsistency ratios are below $10 \%$, the decision matrices that are prepared for the criteria are consistent.

\section{Conclusions}

\subsection{Analysis of overall factors and BOCR}

The economic parameters (with a weight of 0.626) exert the most significant impact on structure of BOCR in case of newsprint paper industry privatization. Of economic parameters, both tax law and GDP trend have a weight of 0.50 . High taxes on wood and paper industry weaken financial supports for its privatization because high taxes create barriers against investment. GDP has influence in private sectors. The performance of privatized paper industry depends on the volume of paper production, and influence of rivals especially the prices of their produced papers. Results with regard to benefits show that an economic criterion is the most important factor which influences privatization of newsprint paper in the country. Regarding to economic criteria, joining to world trade organization (0.582), decrease of budget deficiency and national $\operatorname{debts}(0.506)$ and adjustment of subsides and decrease price changing (0.442) have the highest priority. With respect to costs, economic criteria (0.769) have the highest priority in comparison 
with social criteria $(0.231)$. Final result shows regard to economic criteria, limiting rules \& heavy taxes (0.614) have the highest priority which indicate legislation has an important function in newsprint paper industry. Economic criteria have the highest priority (0.661) regard to opportunities. Final processing (inconsistency ratio: 0.08) shows encouragement possibility and absorption of foreign and internal investment sub criteria with weighing value of 0.375 has the highest priority. Concerning results in part of risks, economic criteria (0.663) has more priority in comparison with social and cultural criteria. After final synthesizing (inconsistency ratio: 0.05), regard to economic criteria, limiting regulative costs (0.289) have the highest priority.

\subsection{Analysis of Highest priority}

As table 2 shows, encouragement for investment has the highest priority (0.376) and is the most useful alternative for privatizing newsprint paper industry. Encouragement for investment has the highest priority in terms of benefits, opportunities, costs and risks (respectively with values of $0.375,0.385,0.472$, and 0.285 ). Encouragement for participating in privatization and developing the related public culture makes biggest gains. It makes the most considerable impact on reduction in budget deficit and national debts as well. In other words, attraction of domestic and foreign investment, and growth of privatized companies lead to increase in their profitability and reduction in budget deficit and capital loss.

Encouragement for investment has highest priority as regards opportunities. Indeed, this alternative provides plenty of opportunities for privatization and economic activities. On the other hand, when privatization process takes place, encouragement for investment provides considerable opportunities. The most significant parameters of opportunity subsets are: Encouragement of domestic and foreign investment, competition with foreign newsprint paper, establishment of legal relations in society and its structures, and attraction of long-standing foreign customers.

Similarly, as far as costs are concerned, encouragement for investment has the highest priority. The greatest costs are associated with limiting rules and high taxes which are subsets of performance criteria. In other words, after taking place as the result of encouragement for 
investment, privatization process deals with administrative costs such as limiting rules and heavy taxes.

The alternative of encouragement for investment involves the highest risks in case of privatization. Clearly speaking, as the greatest weight among risk parameters relates to economic criterion, it involves the highest risk with respect to privatization process in newsprint paper industry. Perhaps, this condition results from capital-based capacity of this industry, expensive prices of related machinery and great sensitivity to privatization.

In risk subsets, limiting legal costs, instability and uncertainty of national economy, social disorders in short term due to unemployment, limited demand, weak financial markets and public jealousy of private entrepreneurship will have the highest effect on encouragement for investment.

For Implementation of economic-structure improvement program and enhancement of economic development, access to foreign financial resources is as much significant as domestic ones. In order to accomplish this purpose, reduction in investment risk should occur. Privatization is the most effective policy that the governments implement in order to attract foreign investment. Stability of rules, tariff system, insurance, employer-employee relations, investment security, special supports of banking system and social security laws are the most important principles in this regard.

\section{Key References}

- Alex, Ng., Yuce, A., Chen, E., 2009.Determinate of state equity ownership and effect on value/ performance: China's privatized firms. Pacific - Basin Finance Journal, 17, 413-443.

- Iran's students scientific site, 2010. Economy privatization. [online]. Iran students' web site. Available from:

http://www.daneshju.ir/forum/f1148/t86141.html

- Mooj news agency, 2008. Paper in Canada. [online]. Paper and wood industry. Available from: http://woodwood.blogfa.com/post-129.aspx

- Saaty T., 2001. Decision Making with Dependence and Feedback: The Analytic Network Process: RWS Publications, Pittsburgh, PA. 